\title{
A Palavra de Deus e a Missão Continental na vida do Sacerdote
}

\author{
Leonardo Agostini Fernandes
}

\section{Introdução}

A Igreja é, por natureza, uma realidade Sacerdotal e Missionária ${ }^{1}$. Esta afirmação reveste-se de particular importância em virtude do momento que estamos vivendo: em nível Católico, o Ano Sacerdotal e, em nível Continental, a exigência da Missãó ${ }^{2}$.

A Igreja é Sacerdotal porque foi gerada, vive e se nutre de Jesus Cristo, Sumo e Eterno Sacerdote da Nova e Eterna Aliança. A dinâmica da Última Ceia é o centro vital desta característica da Igreja, pois foi nela que o Senhor Jesus deixou-se a Si mesmo como Eucaristia e mandou que seus discípulos a celebrassem como memorial perene até o seu retorno: "fazei isto em memória de mim" (Lc 22,19-20; 1Cor 11,24-25).

A Igreja é Missionária porque segue os passos e os exemplos deixados por Jesus que assumiu, por não ter onde reclinar a cabeça (cf. Mt 8,20), uma dinâmica missionária. Ele percorria as aldeias e povoados da Palestina, instaurando o Reino de Deus ${ }^{3}$, por palavras e ações, dizendo: “Arrependei-vos,

\footnotetext{
${ }^{1}$ Cf. CONC. ECUM. VAT. II, Const. Dogm. Lumen Gentium, nn. 10-11; Decr. Ad Gentes, n. 5.

${ }^{2}$ A dinâmica e a metodologia, que animaram a V Conferência Geral do Episcopado LatinoAmericano e do Caribe, resultou no Documento de Aparecida, que propõe a perspectiva e a exigência missionária no processo de formação dos discípulos de Jesus Cristo.

${ }^{3}$ De forma muito consciente, Bento XVI lembra que: "Certamente, não podemos 'construir' o Reino de Deus com as nossas forças; o que construímos permanece sempre reino do homem com todos os limites próprios da natureza humana. O reino de Deus é um dom, e por isso mesmo é
} 
porque está próximo o Reino dos Céus." (Mt 4,17b). Jesus tinha clareza e certeza quanto ao envio recebido do Pai e do que queria para a sua Igreja, comunidade de discípulos missionários: "Como o Pai me enviou, também eu vos envio." (Jo 20,21)

Jesus, no exercício da sua missão, diante de uma dúvida doutrinal que os discípulos apresentaram, sobre a transmissão do pecado em família, disse: "Enquanto é dia, temos de realizar as obras daquele que me enviou; vem a noite, quando ninguém pode trabalhar. Enquanto estou no mundo sou a luz do mundo." (Jo 9,4-5).

Esta auto definição, como luz do mundo, foi dilatada aos que Jesus associou a Si:

"Vós sois a luz do mundo. Não se pode esconder uma cidade situada sobre um monte. Nem se acende uma lâmpada e se coloca debaixo do alqueire, mas na luminária, e assim ela brilha para todos os que estão na casa. Brilhe do mesmo modo a vossa luz diante dos homens, para que, vendo as vossas boas obras, eles glorifiquem vosso Pai que está nos céus." (Mt 5,14-16)

Nestes dois textos, reside uma forte exigência: as obras da luz devem ser manifestas diante do mundo. Assim como Jesus opera, durante o dia, realizando as obras do Pai, também os seus discípulos devem, às claras, glorificar o Pai através das suas obras.

A Igreja existe, portanto, como luz do mundo para cumprir um mandato: "Ide por todo o mundo, proclamai o Evangelho a toda criatura." (Mc 16,15). E, por este mandato, deve cumprir uma profecia que expressa a vontade de Deus:

"Mas vós sois uma raça eleita, um sacerdócio real, uma nação santa (cf. Lv 19,2), o povo de sua particular propriedade, a fim de que proclameis as excelências daquele que vos chamou das trevas para sua luz maravilhosa, vós que outrora não éreis povo, mas agora sois o povo de Deus, que não tínheis alcançado misericórdia, mas agora alcançastes misericórdia." (1Pd 2,9-10)

Dentro da dinâmica, das motivações e das prioridades do Ano Sacerdotal e da Missão Continental, que se alimentam dos ecos e dos frutos do Ano Paulino, apenas concluído, e do Ano Catequético, em pleno andamento

grande e belo, constituindo a resposta à esperança" (Carta Encíclica Spe Salvi. [Paulinas, São Paulo, $\left.2008^{3}\right]$, n. 35). 
e efervescência na Igreja do Brasil, minha fala buscará ressaltar uma urgência: precisamos nos empenhar para sermos sacerdotes segundo o querer de Deus, que nos chamou. Para isso, é urgente que sejamos sacerdotes com um profundo espirito missionário, buscando ter, para o bom exercício da nossa vocação e missão, um novo ardor pelas Sagradas Escrituras, tornando-nos sacerdotes bíblicos, e não, simplesmente, sacerdotes com formação bíblica.

\section{Esclarecendo os dois tópicos}

Por espírito missionário, entende-se o esforço da Igreja, animada pelo Espírito Santo, para levar a Boa Nova de Jesus Cristo, aos homens, apresentando e articulando os conteúdos da fé, não só usando textos bíblicos, mas buscando realizar e propor um percurso de formação que leve o sacerdote e seus colaboradores a acessar, conhecer, viver e amar a Palavra de Deus ${ }^{4}$. Isto é, buscando nela a capacidade para superar as tentações, as seduções do dia a dia, mas, principalmente, o desânimo diante dos nossos fracassos e fraquezas humanas.

Um bom exemplo disso encontra-se na resposta que Jesus deu ao Tentador antes de iniciar a sua vida pública como missionário do Pai: "não só de pão vive o homem, mas de toda palavra que sai da boca de Deus." (Mt 4,4). Esta atitude de Jesus deve se tornar o critério indispensável para que a vida do sacerdote e dos seus colaboradores transcorra de forma ministerial, isto é, na diaconia a Deus e aos homens.

Por Sacerdote bíblico, entende-se aquele que, deixando-se modelar pelo Espírito Santo, acessa, conhece, ama e sabe utilizar a Palavra de Deus na própria vida e nos encontros de formação, animando a vida da comunidade ${ }^{5}$. Isto, porém, não só citando certos textos para os paroquianos, a fim de fundamentar suas teorias, mas porque transmite e ensina a Palavra de Deus com a palavra e a vida, dando o testemunho coerente que Jesus exige de seus discípulos.

Exemplificamos estes dois tópicos com três textos evangélicos.

“Nem todo aquele que me diz 'Senhor, Senhor' entrará no Reino dos Céus, mas sim aquele que pratica a vontade de meu Pai que está nos céus. Muitos me dirão naquele dia:

\footnotetext{
${ }^{4}$ Cf. CONGREGAÇÃO PARA O CLERO, Diretório para o Ministério e a Vida do Presbitero. Vozes, Petrópolis, 1994, nn. 14-15.

5 "Para tal fim, ele [sacerdote] deve sentir-se empenhado pessoalmente em cultivar a Sagrada Escritura com o estudo de uma sã exegese, sobretudo patrística, e com a mediação feita segundo os diversos métodos comprovados pela tradição da Igreja, de maneira a obter dela uma compreensão animada pelo amor." (Diretório para o Ministério, n. 46)
} 
'Senhor, Senhor, não foi em teu nome que profetizamos $e$ em teu nome que expulsamos demônios e em teu nome que fizemos muitos milagres?' Então eu lhes declararei: 'Nunca vos conheci. Apartai-vos de mim, vós que praticais a iniqüidade'. Assim, todo aquele que ouve essas minhas palavras e as põe em prática será comparado ao homem sensato que construiu sua casa sobre a rocha. Caiu a chuva, vieram as enxurradas, sopraram os ventos e deram contra aquela casa, mas ela não caiu, porque estava alicerçada na rocha. Por outro lado, todo aquele que ouve essas palavras, mas não as pratica, será comparado ao homem insensato que construiu a sua casa sobre a areia. Caiu a chuva, vieram as enxurradas, sopraram os ventos e deram contra aquela casa, e ela desmoronou. E foi grande a sua ruina! Aconteceu que ao terminar Jesus essas palavras, as multidões ficaram extasiadas com o seu ensinamento, porque as ensinava com autoridade e não como os seus escribas." (Mt 7,21-29)

Nesta advertência, feita por Jesus Cristo, percebe-se uma crítica bem radical ao uso que se estava fazendo ou que se faz de certos carismas: profecia, exorcismo e milagres. A Boa Nova de Jesus não consiste, simplesmente, na busca ou na prática de ações que chamam a atenção dos interlocutores.

$\mathrm{O}$ que conta na vida de um sacerdote, comprometido com Jesus Cristo e com o espírito missionário, que anima a sua Igreja, é não prescindir da sua vocação e missão: cumprir, a exemplo de Jesus, a vontade do Pai.

$\mathrm{O}$ que corrobora o ensinamento da Palavra de Deus feito com autoridade é a vida de coerência. As pessoas, às quais somos enviados em missão, darão crédito à nossa pregação, na medida em que perceberem a eloqüente ligação entre o "dizer" e o "praticar" a verdade. A coerência é algo decisivo para a salvação tanto de quem prega, como de quem escuta a Boa Nova.

“Jesus, aproximando-se deles, falou: 'Todo poder me foi dado no céu e sobre a terra. Ide, portanto, e fazei que todas as nações se tornem discípulos, batizando-as em nome do Pai e do Filho e do Espírito Santo e ensinando-as a observar tudo quanto vos ordenei. E eis que eu estou convosco todos os dias, até a consumação dos séculos." (Mt 28,18-20).

O poder de Jesus Ressuscitado sobre a morte é o que alimenta e vitaliza a missão, que expõe, continuamente, o discípulo ao martírio. Assim, o sacerdote é animado não só pelo poder de Jesus, mas, principalmente, pelo 
seu vínculo pessoal com Ele, experimentando, em primeira pessoa, a dinâmica da presença e da assistência de Jesus Cristo. Os eventos da história e da missão universal da Igreja se robustecem pela certeza e pela eficácia viva e operosa do Espírito Santo.

\begin{abstract}
"Jesus fez ainda, diante de seus discípulos, muitos outros sinais, que não se encontram escritos neste livro. Esses, porém, foram escritos para crerdes que Jesus é o Cristo, o Filho de Deus, e para que, crendo, tenhais vida em seu nome." (Jo 20,30-31).
\end{abstract}

O que Jesus Cristo fez e ensinou se tornaram as credenciais que transformaram a vida e a qualidade da fé dos apóstolos. Por eles se difunde uma novidade e, os que foram alcançados pelo testemunho apostólico, agora posto por escrito nos Evangelhos, entram em contato vivo com Jesus Cristo.

Assim, a missão e o exercício sacerdotal estão fundamentados em Jesus Cristo. Ele realizou as expectativas messiânicas para além da história do seu povo. Portanto, suscitar e defender a fé em Jesus Cristo, o Filho de Deus, são dois objetivos que acontecem graças ao testemunho vivo e perene dos apóstolos enviados em missão. Por este testemunho, todos os fiéis se tornam participantes da mesma vida do Filho de Deus.

\title{
2. Ampliando os dois tópicos
}

Aproveitando os ecos e os valiosos frutos do Ano Paulino, apenas concluído, utilizarei o texto de $1 \mathrm{Tm}$ 4,1-7 na reflexão deste ponto.

"O Espírito diz expressamente que nos últimos tempos alguns renegarão a fé, dando atenção a espiritos sedutores e a doutrinas demoníacas, por causa da hipocrisia dos mentirosos, que têm a própria consciência como que marcada por ferro quente; eles proíbem o casamento, exigem a abstinência de certos alimentos, quando Deus os criou para serem recebidos, com ação de graças, pelos que têm fé e conhecem a verdade. Pois tudo o que Deus criou é bom, e nada é desprezivel, se tomado com ação de graças, porque é santificado pela Palavra de Deus e pela oração. Expondo estas coisas aos irmãos, serás bom servidor de Cristo Jesus, nutrido com as palavras da fé e da boa doutrina que tens seguido. Rejeita, porém, as fábulas ímpias, coisas de pessoas caducas. Exercita-te na piedade." 
Acredito que este texto pode apontar pistas concretas para o exercício do nosso sacerdócio, para que, sendo bíblico, forme e conte com colaboradores bíblicos.

$\left.1^{o}\right)$ O conhecimento da Bíblia, como alma da Teologia ${ }^{6}$ e, portanto, alma da missão, é, sem dúvida alguma, indispensável. Paulo exorta Timóteo sobre os desvios doutrinais que apareceram em sua época e que estão muito acentuados na nossa época.

Deve-se perceber que o sacerdote e os seus colaboradores só podem conhecer os desvios doutrinais se conhecem a verdade, do contrário, os fiéis acabarão sendo um alvo fácil dos sedutores da fé e da verdade. Estes sedutores se utilizam da Palavra de Deus para convencer e fazer proselitismo, dizendo que o seu modo de ler, entender e interpretar a Bíblia é o correto.

$\mathrm{O}$ antídoto para isto encontra-se numa advertência feita por Jesus aos judeus que nele haviam crido: "Se permanecerdes na minha palavra, sereis verdadeiramente meus discipulos e conhecereis a verdade e a verdade vos libertará." (Jo 8,31-32).

$\left.2^{\circ}\right)$ O que de bom existe é obra de Deus e vai tomado com ação de graças pelos que têm fé e conhecem a verdade. Vivemos momentos difíceis em todos os níveis e extratos da sociedade. Hoje, mais do que nunca, a busca pela ascensão fácil na vida social, política, econômica, até eclesial, e pela obtenção desenfreada dos bens de consumo tornou-se um imperativo dentro e fora da Igreja. O único escrúpulo que reina é o de deixar de fazer aquilo que puder trazer benefícios próprios. Parece que o ilegal é não tirar vantagem. Esta dinâmica está, sutilmente, na base da falsa teologia da prosperidade apregoada, acentuada pelas seitas pentecostais e, até mesmo, por certos sacerdotes.

O sacerdote, pela leitura assídua, pelo estudo e pelo conhecimento da Palavra de Deus, rejeita, em primeira pessoa, tudo aquilo que não condiz com a verdade, custe o que custar, aceitando viver o martírio. A hipocrisia dos mentirosos é a tentativa de justificar o erro próprio e dos outros utilizando-se, até mesmo, da autoridade da Palavra de Deus (cf. Rm 12,9).

Se o problema na época de Paulo girava em torno do casamento e da abstinência de certos alimentos, hoje, não se casar, mas se juntar, e rejeitar ou abusar de alguns alimentos viraram uma quase regra. O consumo do sexo e da comida são os dois fortes eixos sobre os quais a sociedade capitalista está girando. Os "restaurantes do sexo e da comida" trabalham a la carte e self service, aceitando todos os cartões de crédito.

Os maiores problemas que estamos enfrentamos na missão, com a evangelização e a catequese, residem num fato preocupante: nossas famílias

\footnotetext{
${ }^{6}$ Cf. CONC. ECUM. VAT. II, Const. Dogm. Dei Verbum, n. 24.
} 
estão sendo desagregadas pela ambição desmedida de muitos políticos. Seguindo a onda do mercado dos votos, alguns apóiam a destruição da família, propondo e querendo aprovar leis que darão a dois homens ou a duas mulheres que se unem, os mesmos direitos dos que buscam formar uma família segundo os critérios bíblicos que expressam a vontade do Criador para o homem e para a mulher:

"Não é bom que o homem esteja só. Vou fazer uma auxiliar que lhe corresponda... Então o homem exclamou: 'Esta, sim, é osso de meus ossos e carne de minha carne"' (Gn 2,18.23; cf. Mt 19,4-6).

A laicização da sociedade, com a exclusão das leis de Deus, terá um alto preço a pagar e as conseqüências serão drásticas, pois estão violando e violentando a família ${ }^{7}$.

A família é o que de melhor Deus criou e não se deve desprezá-la, mas santificá-la pela Palavra de Deus, pela oração e por iniciativas públicas que salvaguardem os seus direitos fundamentais ${ }^{8}$.

Para que a Missão Continental seja bíblica, e seja feita, então, por sacerdotes bíblicos, será necessária a reunião de esforços, através de uma ação que seja capaz de mostrar que a Igreja é, por vontade de Deus, a guardiã da integridade e da missão da família na sociedade (cf. Mt 19,1-9; Ef 5,21-32; 1Pd $3,1-7)^{9}$.

A Missão Continental revitalizará o mundo católico, em terras latinoamericanas, se os sacerdotes, em primeiro lugar, colocarem a Palavra de Deus como prioridade em suas atividades pastorais. Ser sacerdote bíblicomissionário, formando agentes de pastorais que tenham zelo e conhecimento da Palavra de Deus, urge como grande desafio neste início de Milênio.

Para lutar, com astúcia e prudência, contra os desvios doutrinais causados pelos que arrebanham mais e mais pessoas em nosso Continente, com a Bíblia nas mãos, deve-se seguir a exortação de Paulo:

"Eu te conjuro, diante de Deus e de Cristo Jesus, que há de vir julgar os vivos e os mortos, pela sua Aparição e por seu Reino: proclama a palavra, insiste, no tempo o-

\footnotetext{
${ }^{7}$ Cf. Documento de Aparecida, nn. 436.

${ }^{8}$ Cf. JOÃO PAULO II, PP., "A família cristã respeitada e estável constitui a essência da comunidade eclesial", em Palavra do Santo Padre ao Brasil. Paulinas, São Paulo 1991, 117-125; AFONSO LÓPEZ TRUJILLO, "La Verdad de la Familia", em Familia vida y nueva evangelización, EDV, Estella (Navarra) 2000, pp. 175-189.

${ }^{9}$ Cf. Documento de Aparecida, nn. 432-435.
} 


\begin{abstract}
portuno e no inoportuno, refuta, ameaça, exorta com toda paciência e doutrina. Pois virá tempo em que alguns não suportarão a sã doutrina; pelo contrário, segundo os seus próprios desejos, como que sentindo comichão nos ouvidos, se rodearão de mestres. Desviarão os ouvidos da verdade, orientando-os para as fábulas. Tu, porém, sê sóbrio em tudo, suporta o sofrimento, faze o trabalho de evangelista, realiza plenamente teu ministério." (2tm 4,1-5)
\end{abstract}

$\left.3^{\circ}\right)$ Expor a sã doutrina é um serviço que cada sacerdote prestará, como Timóteo, aos seus irmãos de comunidade. Todavia, para isso acontecer, é preciso ser bom servidor de Cristo Jesus, nutrir-se com a fé e com a boa doutrina, rejeitando as fábulas, isto é, aquilo que se passa por boa doutrina, e exercitando-se na piedade.

Neste terceiro tópico reside a exigência: nossa Missão Continental será bíblica se ela puder contar com sacerdotes dispostos a buscar, com esmero, a sua atualização bíblica, não se contentando a ser meros repetidores de um roteiro homilético ou livro de exegese. Por melhor que estes instrumentos possam ser, eles serão, somente, instrumentos. Nenhum deles poderá substituir a leitura, meditação e oração diárias com Palavra de Deus, principalmente pela Lectio Divina, deixando-se modelar por ela, a fim de que a fé viva seja transmitida às pessoas que foram encontradas por Jesus Cristo e por Ele tiveram suas vidas transformadas.

\title{
3. Aprofundando o tema
}

Quem encontra Jesus Cristo, ou melhor, quem é encontrado por Ele e não tem sua vida transformada, ainda não fez uma verdadeira experiência da fé libertadora.

Queremos desenvolver este tópico, partindo de dois textos do Evangelho Segundo São Marcos, que está nos acompanhando neste ciclo litúrgico B.

"Depois subiu à montanha, e chamou a si os que ele queria, e eles foram até ele. E constituiu Doze, para que ficassem com ele, para enviá-los a pregar, e terem autoridade para expulsar os demônios. Ele constituiu, pois, os Doze, e impôs a Simão o nome de Pedro; a Tiago, o filho de Zebedeu, e a João, o irmão de Tiago, impôs o nome de Boanerges, isto é, filhos do trovão, depois André, Filipe, Bartolomeu, Mateus, Tomé, Tiago, o filho de Alfeu, Tadeu, Simão o Zelota, e Judas Iscariot, aquele que o entregou." (Mc 3,13-19) 
"E ele percorria os povoados circunvizinhos, ensinando.

Chamou a si os Doze e começou a enviá-los dois a dois. E deu-lhes autoridade sobre os espíritos impuros. Recomendou-lhes que nada levassem para o caminho, a não ser um cajado apenas; nem pão, nem alforje, nem dinheiro ao cinto. Mas que andassem calçados com sandálias e não levassem duas túnicas. E dizia-lhes: 'Onde quer que entreis numa casa, nela permanecei até vos retirardes do lugar. E se algum lugar não vos receber nem vos quiser ouvir, ao partirdes de lá, sacudi o pó de debaixo dos vossos pés em testemunho contra eles'. Partindo, eles pregavam que todos se arrependessem. E expulsavam muitos demônios, e curavam muitos enfermos, ungindo-os com óleo." (Mc 6,6b-13)

O chamado, nestes dois textos, é fundamental: Jesus chamou a si os que ele quis. O chamado é a nota característica do sacerdote ${ }^{10}$. Ele é um chamado por Jesus para ser um instrumento vivo e eficaz da sua Palavra na sua Igreja. Ao lado disto, é preciso dizer que a Igreja não vive de voluntários ou de voluntariado. Ela é feita de convocados que estão a serviço de uma missão exercida como um verdadeiro ministério. $\mathrm{O}$ sacerdote é um ministro da Palavra de Deus para os que a Igreja lhes confia.

Este ministério é, porém, o exercício próprio e específico do Bispo, um sucessor dos Apóstolos que, pelos dois textos, foram os chamados e comissionados para, em primeiro lugar, estar com Jesus, para serem enviados e para terem autoridade sobre os demônios; em segundo lugar, para crerem que o essencial na missão é ter a autoridade representada por um bastão e ter a dignidade representada pelo par de sandálias.

O bastão é, no Antigo Testamento, um instrumento que lembra as grandes façanhas realizadas por Deus através de Moisés para libertar o povo eleito do cativeiro e da opressão egípcias. É, também, o símbolo do pastoreio, que Moisés tem nas mãos para conduzir o povo, rebanho de Deus, com sandálias aos pés, rumo à terra prometida ${ }^{11}$.

Não nos esqueçamos que entre a libertação do Egito e a entrada na terra prometida, o período do deserto aconteceu como um momento essencial para a formação do povo, recebendo a Lei de Deus como seu tutor.

Estas imagens foram recuperadas por Jesus no Novo Testamento. Seus Apóstolos assumem, ao lado de Jesus, o pastoreio do povo que precisa e clama por libertação dos demônios.

\footnotetext{
${ }^{10}$ Cf. CONGREGAÇÃO PARA O CLERO, Diretório para o Ministério, n. 4.

${ }^{11}$ Cf. MANFRED LURKER, "Bastão", em Dicionário de Figuras e Símbolos Bíblicos. Paulus, São Paulo 1983, pp. 23-24.
} 
Hoje, muitos homens são mantidos no cativeiro da ganância, do poder e na pior opressão: a ignorância sobre o amor de Deus. Ao invés de estarem sendo conduzidos para a terra prometida, estão vivendo sem sandálias, isto é, debaixo das fábulas, com exortava Paulo ao seu bispo auxiliar, Timóteo.

A vocação e a missão do sacerdote e de seus colaboradores consistem, então, num tripé de ações: pregar o arrependimento dos pecados, expulsar os demônios e curar os doentes, ungindo-os com o óleo.

\subsection{Pregar o arrependimento}

Quando encontrados por Jesus Cristo, que é a Palavra Eterna e Última de Deus Pai ${ }^{12}$, experimenta-se o Amor de Deus derramado em nossos corações. Somos alcançados pela infinita misericórdia de Deus que quer perdoar. É o que Deus nos diz, através de Ezequiel: "Porventura tenho eu prazer na morte do ímpio?... Eu não tenho prazer na morte de quem quer que seja, oráculo do Senhor Adonai. Convertei-vos e vivereis!" (Ez 28,23.32).

Somente pessoas arrependidas ou que experimentaram o amor infinito e bondoso de Deus em suas vidas podem se tornar eficazes servidores da Palavra de Deus, isto é, promotores do amor do Pai, revelado por Jesus, na força do Espírito Santo. Esta foi a missão que Jesus assumiu para si e que confiou aos seus discípulos.

O Ano Sacerdotal e a Missão Continental alcançarão o êxito desejado pela Igreja se nós, sacerdotes, permitirmos, primeiramente, que Deus nos restaure por seu amor, tornando-nos instrumentos capazes de comunicar esse amor aos homens como quis o próprio Deus: "Pois Deus amou tanto o mundo, que entregou o seu Filho único, para que todo o que nele crê não pereça, mas tenha a vida eterna."13

Um outro exemplo encontra-se em Mt 9,10-13.

\subsection{Expulsar os demônios}

Há quem negue a existência do demônio ${ }^{14}$. Todavia, a maior sedução que o demônio pode fazer aos homens, principalmente aos estudiosos da Bíblia, é levá-los a acreditar que ele não existe, e muitos sacerdotes assim o pensam e ensinam ao povo. Todavia, apesar de considerar o demônio como

\footnotetext{
${ }^{12}$ Cf. CONC. ECUM. VAT. II, Const. Dogm. Dei Verbum, n. 2.

${ }^{13}$ Cf. Diretório para o Ministério, nn. 51-54.

${ }^{14}$ Ver a respeito, AMADOR-PEDRO BARRAJÓN MUÑOZ, “Al inicio Dios creó...” (Gn 1,1) Ángeles y demonios em el plan de la salvación. Mater et Magistra, México 1999, pp. 55-106.
} 
um ser pessoal e inteligente ${ }^{15}$, nós devemos avaliar o que está por detrás da palavra demônio.

Em nossa sociedade, é demônio e demoníaco tudo aquilo que desvirtua a imagem e a vontade de Deus, inclusive aquilo que é falado em nome de Deus e com a Bíblia nas mãos. Se antes o principal instrumento dos roubos e assassinatos era uma arma, hoje, vários roubam e matam usando a Bíblia como uma verdadeira arma exterminadora.

É alarmante, existe um crime organizado, que está utilizando a Palavra de Deus, numa grande variedade de meios de comunicação, para seduzir as pessoas e mantê-las escravas de um projeto de falsa evangelização do Brasil, da América Latina e dos países pobres. Está em ação uma nova forma de colonização: o fundamentalismo.

Um outro exemplo encontra-se em Mc 1,21-28.

\subsection{Curar os doentes, ungindo-os com o óleo}

Lendo isto no texto de Marcos não se levanta suspeita, mas uma santa curiosidade. Não se trata, neste momento, a meu ver, de uma clara notícia sobre o sacramento da Unção dos Enfermos (a Igreja, assim, o lerá depois, cf. Tg 5,14), mas de um meio muito eficaz de se tratar as feridas no mundo antigo. As propriedades terapêuticas do óleo de oliva são conhecidas em toda a região que cerca a terra de Jesus e de seus discípulos ${ }^{16}$.

Curar e ungir são dois verbos que intensificam a vocação e a missão da Igreja e nela de cada membro comprometido com a evangelização, principalmente os sacerdotes.

Ao mandar curar, Jesus Cristo se posiciona diante das limitações e das fragilidades da natureza humana. Isto mostra o quanto nós e o povo de Deus somos frágeis e necessitados de saúde corporal e espiritual.

Ao mandar ungir, Jesus Cristo evidencia e compartilha o que é determinante na sua Encarnação e Missão. Ele é o Messias, o Ungido pelo Espírito de Deus, isto é, o consagrado "para evangelizar os pobres, para proclamar a libertação dos presos e aos cegos a recuperação da vista, para restituir a liberdade aos oprimidos e para proclamar um ano da graça do Senhor." (Lc 4,18s).

Um outro exemplo encontra-se em Lc 10,29-38.

\footnotetext{
${ }^{15}$ Cf. PAULO VI, PP. Catequese da audiência geral de 15 de novembro de 1972, em Insegnamenti di Paulo VI. Tipografia Poliglotta Vaticana, Roma, pp. 1169-1170.

${ }^{16}$ Cf. RUDOLF PESCH, Il Vangelo di Marco [Parte prima]. Paideia, Brescia 1980, p. 515.
} 


\section{Alguns passos concretos, que podemos e devemos dar, para vivermos este Ano Sacerdotal com um novo ardor Missionário}

O primeiro século da fé e difusão do Evangelho de Jesus Cristo foi, por um lado, muito promissor, mas, por outro lado, muito conturbado e com grandes dificuldades para os seus discípulos. A Igreja, segundo o relato dos Atos dos Apóstolos, crescia em número e em locais (cf. At 2,41.47; 9,31), porque a evangelização contava, de modo particular, com a incansável atuação do apóstolo Paulo e de seus colaboradores.

Ao que tudo indica, seguindo a tradição, visto que carecemos de notícias bíblicas a respeito, alguns apóstolos formaram comunidades e se instalaram nelas. Tomé, após evangelizar a Síria e a Pérsia, teria levado a Boa Nova para a Índia ${ }^{17}$. Tiago Maior teria passado pessoalmente ou seu corpo teria sido levado para a Espanha, originando a cidade de São Tiago de Composte$1 \mathrm{a}^{18}$. Pedro, provavelmente, chegou a Roma, antes de Paulo, e junto com ele sofreu o martírio entre os anos 65-70 d.C. João teria sido uma espécie de metropolita, animando e cuidando, a partir de Éfeso ${ }^{19}$, das igrejas fundadas na Ásia Menor, num circuito que se comunicava por estradas. São as Sete Igrejas que aparecem no início do livro do Apocalipse (cf. Ap 2,1-3,20).

Este último tópico da nossa conferência pautar-se-á em algumas exortações que Jesus Cristo dirige, através de João, irmão e companheiro na tribulação, no reino e na firmeza em Jesus (Ap 1,9), às Sete Igrejas.

As exortações podem servir de passos concretos, porque os problemas enfrentados pelas Sete Igrejas da Ásia Menor continuam atuais em nossas comunidades. Tomemos estes problemas não como obstáculos, mas como os desafios da nossa vida sacerdotal e da missão à qual somos chamados a realizar, com novo ardor, em nosso Continente.

4.1 À igreja de Éfeso é dito: "Devo reprovar-te, contudo, por teres abandonado teu primeiro amor" (Ap 2,4)

Diz um ditado popular: "o primeiro amor nunca se esquece". Parece-me que o texto bíblico confirma este ditado, mas afirma, para nossa tristeza, que o primeiro amor, porém, pode ser abandonado ${ }^{20}$. Será que ainda nos lembramos

\footnotetext{
${ }^{17}$ Cf. Eusébio de Cesaréia, História Eclesiástica 3,1; Atos de Tomé 1-2.17-19.

${ }^{18}$ Cf. PAPA BENTO XVI, Os Apóstolos. Uma introdução às origens da fé cristã. Pensamento, São Paulo, 2008, p. 79.

${ }^{19}$ Cf. PAPA BENTO XVI, Os Apóstolos, p. 91.

${ }^{20}$ A Igreja, e nela cada fiel, se não mantém o nível, o vigor e a vibração do amor inicial, corre o risco de perder a comunhão (cf. HUGO VANNI, Apocalipse. Paulinas, São Paulo 1979², pp. 42-45;
} 
do momento em que Jesus nos alcançou com a sua graça e nos chamou, isto é, a sermos seus discípulos e missionários do seu Reino de Amor?

O primeiro passo consiste em lembrar, reviver e renovar o primeiro amor de nossa vocação e missão sacerdotal, pois só o amor é capaz de curar nossas feridas e nossas infidelidades cometidas no exercício do ministério sacerdotal.

Esta exortação nos convida a recuperar o ardor e o entusiasmo, notas típicas de quem ama e luta pela pessoa amada e seus interesses. Nossa vida e atividades pastorais serão fecundas, ricas em frutos, se o nosso amor for autêntico, isto é, se nós permanecermos inseridos e unidos a Jesus Cristo que é a Videira Verdadeira (cf. Jo 15,1-17).

\section{2 À igreja de Esmirna é dito: "Não tenhas medo do que irás sofrer" (Ap 2,10)}

Quem ama sofre! É uma afirmação forte, porque "o sim ao amor é fonte de sofrimento, porque o amor exige sempre expropriações do meu eu, nas quais me deixo podar e ferir., ${ }^{21}$

Nosso Senhor Jesus Cristo, em primeiro lugar, deu-nos o exemplo, porque quis, enquanto Verdade e Amor encarnados, sofrer por nós e conosco: "Ninguém tem maior amor do que aquele que dá a vida por seus amigos." (Jo $15,13)$.

Se Jesus nos chamou por puro amor, também nos chamou, misteriosamente, a amar e a sofrer por Ele, com Ele e para Ele. Quem se dispõe a doarse, deve correr os riscos da sua entrega a Jesus Cristo e às pessoas que recebemos para guiar ou que estão à nossa espera. A morte, pelo martírio, faz parte da vida cristã ${ }^{22}$.

Creio que o Ano Paulino deixou isto bem claro para nós. Ao chamar Paulo para o ministério, disse o Senhor a Ananias:

"Mas o Senhor insistiu: 'vai, porque este homem é para mim um instrumento de escol para levar o meu nome diante das nações pagãs, dos reis e dos israelitas. Eu mesmo lhe mostrarei quanto lhe é preciso sofrer em favor do meu nome" (At 9,15-16)

O segundo passo consiste em aceitar, amar e transformar nossos sofrimentos - abandono, solidão, incompreensão, calúnias, pecados etc - em obla-

ISIDORO MAZZAROLO, O Apocalipse: esoterismo, profecia, ou resistência? EST, Porto Alegre 1999, p. 34)

${ }^{21}$ Bento XVI, Spe Salvi, n. 38.

${ }^{22}$ Cf. EDUARD LOHSE, L'Apocalisse di Giovanni. Paidéia, Brescia 1974, p. 54. 
ção. Se, por um lado, ninguém escolhe se vai ou não sofrer, por outro lado, cada um de nós pode escolher sofrer por amor à vocação e à missão que nos configuraram a Jesus Cristo ${ }^{23}$.

Esta exortação aplica, aos sacerdotes em dificuldades, o mistério inefável e repleto do amor de Jesus Cristo, nosso redentor. Através da morte cotidiana de nossas vontades e paixões desordenadas, podemos experimentar o êxodo decisivo que se celebra no Mistério Pascal de Jesus Cristo, atualizando-o em cada um de nós. Assim, a vida natural e a vida sobrenatural são recebidas e valorizadas como dons divinos.

4.3 À igreja de Pergamo é dito: "Converte-te, pois! Do contrário, virei logo contra ti, para combatê-los com a espada da minha boca" (Ap 2,16)

Para amar e sofrer, por Cristo, com Cristo e em Cristo, necessitamos de conversão. Ela é um elemento constante na nossa caminhada e empenhativo na nossa configuração sacerdotal a Jesus Cristo. O chamado à conversão é um imperativo categórico que ressoa nos nossos ouvidos, ecoa no nosso coração e se instala na nossa consciência. Não é à toa que, todos os dias, buscamos fazer o exame de consciência ${ }^{24}$.

O terceiro passo consiste em aderir à proposta de Deus em seu Filho, Jesus Cristo, que nos chama, cotidianamente, ao arrependimento e à conversão. Foi assim que ele iniciou a missão para instaurar o Reino de Deus que se transfigura em Reinado de Deus na medida em que a conversão acontece na nossa vida e exercício sacerdotal.

Esta exortação é um fundamentado chamado à mudança de mentalidade, onde a Palavra de Deus, semelhante à uma espada afiada, é o instrumento decisivo para que façamos o discernimento das nossas ações morais e espirituais.

4.4 À igreja de Tiatira é dito: "Reprovo-te, contudo, pois deixas em paz Jezabel, esta mulher que se afirma profetiza: ela ensina e seduz meus servos a se prostituirem, comendo das carnes sacrificadas aos idolos." (Ap 2,20)

No exercício da vocação e missão sacerdotal reside o compromisso com a verdade. "Jezabel", muitas vezes, está circulando livremente em nossas

\footnotetext{
23 'Não é o evitar o sofrimento, a fuga diante da dor, que cura o homem, mas a capacidade de aceitar a tribulação e nela amadurecer, de encontrar o seu sentido através da união com Cristo, que sofreu com infinito amor... A grandeza da humanidade determina-se essencialmente na relação com o sofrimento e com quem sofre.” (Bento XVI, Spe Salvi, n. 37.38)

${ }^{24}$ Quando há uma verdadeira conversão e penitência, o juízo divino é aplacado e por elas satisfeito (Cf. EDUARD LOHSE, L'Apocalisse, p. 57).
} 
comunidades $^{25}$. A sua ação se percebe nos modismos teológicos nefastos que causam graves danos aos fiéis com pouca formação bíblica e teológica.

$\mathrm{O}$ quarto passo consiste no combate às falsas doutrinas, mas, principalmente, na aplicação de todos os esforços para formar o povo de Deus que nos foi confiado, para que ele não caia nas armadilhas do engano. A evangelização e a catequese devem estar no centro das nossas atenções. Precisamos ajudar no processo de formação dos nossos agentes de pastoral. Investir tempo e recursos para dar o que de melhor eles precisam ter para atuar com a Igreja em comunhão com o Bispo.

Esta exortação denuncia que não podemos ter uma mentalidade conformista com a situação hodierna do avanço das seitas, que estão ceifando os batizados em nossas comunidades, e comprometendo, com isso, a fidelidade a Jesus Cristo e à sua Igreja. Para perseverar na ortodoxia da fé não basta não estar no erro, é preciso não deixar que os fiéis sejam conduzidos ao erro. Se, por um lado, não podemos obrigar ninguém a ficar na Igreja Católica, por outro lado, podemos e devemos mostrar a Verdade.

4.5 À igreja de Sardes é dito: "Lembra-te, portanto, de como recebeste e ouviste, observa-o, e converte-te! Caso não vigies, virei como ladrão, sem que saibas em que hora venho te surpreender" (Ap 3,3)

A fidelidade ao depósito da fé é uma condição indispensável para se manter e se promover a unidade $n a$ e $d a$ Igreja. Muitos, hoje, se afastam ou deixam as nossas comunidades porque percebem que não ensinamos com coerência e com consonância com a vida. Muitos percebem que não somos fieis à doutrina da Igreja ou oscilamos na ambigüidade dos conceitos teológicos. Ouve-se dizer: "cada padre, uma sentença." Se somos assim, como os fiéis serão educados na fé e para a vivência da fé? Não estaríamos contribuindo para dividir, ainda mais, o Corpo de Cristo já tão dilacerado?

$\mathrm{O}$ quinto passo exige a fidelidade à voz do Magistério, onde ecoa a voz do próprio Jesus Cristo, a quem devemos nos configurar no exercício sacerdotal. Ele sempre foi fiel aos desígnios do Pai. Sua vontade era fazer a vontade do seu Pai. E nós, somos fiéis?

O respeito e a obediência, prometidos no dia da ordenação, precisam ser renovados cotidianamente em nossa vida sacerdotal.

A exortação mostra, de modo particular, a importância da vigilância. Precisamos acordar em nós o zelo por Jesus Cristo e sua Igreja ${ }^{26}$. Para isso,

\footnotetext{
${ }^{25}$ Sob o epônimo Jezabel está um arquétipo que evidencia a retribuição das ações de acordo com a conduta de cada indivíduo na Igreja (cf. ISIDORO MAZZAROLO, O Apocalipse, p. 39).
} 
devemos sair do torpor diante do conformismo com o erro que mata a fé genuína e faz germinar uma "fé" que engana e ilude. O sacerdote é uma sentinela quando ancorado na tradição apostólica.

4.6 À igreja de Filadélfia é dito: "Venho logo! Segura com firmeza o que tens, para que ninguém tome a tua coroa." $($ Ap 3,11$)$

A Parusia é uma promessa que se realizará no último dia, mas ela já se realiza em cada Eucaristia que presidimos. Que temos, para segurar com firmeza $?^{27}$ Começando pela graça e pelo dom do Batismo, a vocação, a missão e o exercício sacerdotal constituem o tesouro inefável, do qual nós não somos dignos.

O sexto passo consiste em manter-se no sacerdócio e não trocar esse dom precioso por nenhum prato de lentilhas. As seduções e prazeres continuam solicitando-nos. Não percamos de vista o prêmio que está reservado para quem perseverar até o fim.

Esta exortação, a mais breve de todas, nos convida a perseverar na prática do bem. Na maioria das vezes, não veremos os frutos do bem que o Senhor semeia através de nós, mas compensa o fato de estarmos colaborando na edificação do Reino de Deus.

4.7 À igreja de Laodicéia é dito: "Aconselho-te a comprares de mim ouro purificado no fogo para que tu enriqueças, vestes brancas para que te cubras e não apareça a vergonha da tua nudez, e colírio para ungir os olhos e possas enxergar." (Ap 3,18)

Ouro, vestes brancas e colírio são os três elementos indispensáveis para a nossa vida e exercício sacerdotal. São João Crisóstomo se lamentava, dizendo que no início, os cálices eram de madeira e os sacerdotes de ouro, depois, os cálices passaram a ser de ouro e os sacerdotes de madeira ${ }^{28}$.

A riqueza que devemos acumular deriva da importância e da dedicação que damos à Palavra de Deus. Ela é uma fonte para adquirirmos a Sabedoria, que é o sabor pelas coisas de Deus.

\footnotetext{
${ }^{26}$ Às vezes parece que necessitamos ser ameaçados para sair do torpor e da tibieza em que vivemos na Igreja. Lembremo-nos: aquele que vigia pela fé, supera todos os períodos difíceis e de extrema tentação que encontra em sua vida (Cf. EDUARD LOHSE, L'Apocalisse, p. 62).

${ }^{27} \mathrm{O}$ Evangelho, a fé e a palavra, recebidos pela ação missionária dos Apóstolos, quando guardados com fidelidade e testemunhados pela prática das boas obras, estimulam o serviço e encorajam os fiéis tíbios (cf. ISIDORO MAZZAROLO, O Apocalipse, p. 41; EDUARD LOHSE, L'Apocalisse, p. 65).

${ }^{28} \mathrm{Cf}$. Homilias sobre o Evangelho de Mateus, 50,3-4: PG 58,508-509.
} 
A veste branca que cobre a nossa nudez, isto é, o nosso pecado de desobediência, foi-nos dada no dia do Batismo. Esta veste continua nos interpelando e exigindo ser alvejada no Sangue do Cordeiro. Cada vez que nos paramentamos, endossamos essa veste para manifestar a consagração da nossa vida ao Senhor.

O colírio da fé é que nos faz enxergar além das aparências. Ela nos ilumina diante das situações de conflito que deixamos se instalar em nós. Colírio é uma medicina que vai aplicada todos os dias, para limpar as impurezas dos nossos olhos. É o que nos recorda o salmista: "Tua palavra é lâmpada para os meus pés, e luz para o meu caminho." (S1 119,105)

O sétimo passo consiste em buscar as verdadeiras riquezas da nossa vida espiritual e a não perder tempo com as coisas fúteis e discussões inúteis.

Esta exortação alerta para os riscos da auto-suficiência na nossa vida e ministério. Somos dependentes de Jesus Cristo ${ }^{29}$. Somente acolhendo os seus dons, ouro, veste branca e colírio, é que nos manteremos unidos a Ele, participando do mistério da sua paixão, morte e ressurreição com uma inteligência espiritual que nos faz enxergar para além das aparências.

\section{Conclusão}

O percurso que procurei apresentar, nesta breve conferência, consistiu, antes de tudo, numa tentativa de respeitar o momento privilegiado que a Igreja está vivendo com o Ano Sacerdotal. E, no nosso caso particular, com a dinâmica da Missão Continental e do Ano Catequético, que tem por tema: "Catequese, caminho para o discipulado".

Utilizando-me de alguns textos bíblicos, busquei articular, unir e, de algum modo, exemplificar o que está em jogo neste momento privilegiado da nossa história eclesial.

A Igreja deve testemunhar, por palavras e ações, o chamado de Jesus, que nos coloca na dinâmica do discipulado do amor que Ele veio manifestar em sua vida.

Como sacerdotes, nossa tarefa se realizará e se traduzirá de uma forma eficaz se tivermos o apreço zeloso, a escuta fiel e o acesso constante e obediente à Palavra de Deus, seguindo os passos e o mesmo projeto messiânico que Jesus proclamou e abraçou na Sinagoga de Nazaré (Lc 4,16-21 cf. Is 61,1-2). Se naquele dia Ele disse: "Hoje se cumpriu aos vossos ouvidos essa passa-

\footnotetext{
29 "Somente Cristo é capaz de oferecer as riquezas autênticas e que não passam." (PIERRE PRIGENT, O Apocalipse. Loyola, São Paulo $2002^{2}$, p. 91); "A correção é uma forma de aperfeiçoamento; por isso, Deus vai exigindo sempre mais, de modo especial daqueles que ele ama." (ISIDORO MAZZAROLO, O Apocalipse, p. 43).
} 
gem da Escritura." (Lc 4,21), no nosso hoje, como seus discípulos, devemos mostrar que essa passagem continua ecoando e se cumprindo no dia a dia da Igreja que é o seu Corpo.

Jesus Cristo continua demonstrando, através dessas exortações, o amor incondicional pela sua Igreja ${ }^{30}$. Elas servem para a nossa correção e educação da fé. Portanto, se nos dispusermos a ouvir, acolher e meditar estas exortações, que um dia foram feitas às Sete Igrejas da Ásia Menor, um novo ardor e entusiasmo nos revitalizará, tornando-nos disponíveis para seguir Jesus Cristo como verdadeiros discípulos missionários.

Assim, estaremos em consonância com os empenhos assumidos na $\mathrm{V}$ Conferência Geral do Episcopado Latino-Americano e do Caribe realizada em Aparecida $^{31}$.

Que o Ano Paulino, apenas concluído, produza seus mais excelentes frutos na vida dos sacerdotes que celebram, com zelo, o Ano Sacerdotal, apenas iniciado, e o Ano Catequético, em curso no nosso Brasil. Que sejam e sirvam de um grande estímulo à Missão Continental: tornar Jesus Cristo crido, amado e conhecido na Igreja e no mundo, onde o Reino de Deus se transfigura em Reinado de Deus, concretizando o que Jesus fez e ensinou os discípulos a fazerem ao rezarem o Pai Nosso: Pai, seja feita a tua vontade assim na terra como nos céus.

\section{Résumé}

Le parcours présenté dans cet article consiste, avant tout, en une tentative de respecter le moment privilégié que vit l'Église Catholique à notre époque:

a) l'Année Sacerdotale;

b) La dynamique de la Mission Continentale, en particulier dans l'Église latino-américaine;

c) L'Année Catequétique, dans l'Église du Brésil, qui a comme thème: «Catéchèse, chemin pour le disciple de Jésus-Christ».

En employant quelques textes bibliques, on cherche articuler, joindre et, en quelque sorte, exemplifier l'enjeu de ce moment privilégié de notre histoire ecclésiale.

Leonardo Agostini Fernandes

Doutor em Teologia Bíblica pela PUG-Roma Professor do Departamento de Teologia da PUC-RJ

\footnotetext{
${ }^{30}$ Cf. KLEMENS STOCK, L'Ultima Parola è di Dio. L'Apocalisse come Buona Notizia. ADP, Roma $1998^{2}$, pp. 61-65.

${ }^{31}$ V Conferência do Episcopado Latino-Americano e do Caribe. Aparecida: Conclusão. Ed. CNBB - Paulus - Paulinas, São Paulo, 2007.
} 